\title{
The Influence of the Expression of Personality Traits on Growing Intensity of Interdialytic Disorders and Change of Pro-Health Behaviours in CKD Patients.
}

Research article

Keywords:

Posted Date: December 4th, 2020

DOl: https://doi.org/10.21203/rs.3.rs-42324/v3

License: (9) This work is licensed under a Creative Commons Attribution 4.0 International License.

Read Full License 


\section{Abstract}

The authors have requested that this preprint be withdrawn due to author disagreement.

\section{Full Text}

The authors have withdrawn this preprint from Research Square. 